\title{
Unabated Menace of Child Marriage in Nigeria. The Need for an Enabling Constitutional Provision
}

\author{
Kingsley .O. Mrabure Ph.D (Law) \\ Senior Lecturer, Faculty of Law (Oleh Campus), Delta State University,Abraka, Nigeria \\ Mudiaga .K. Ovakporae LL.M
}

\begin{abstract}
This paper examines the menace of unabated child marriage in Nigeria. It defines child marriage in tandem with marriageable age. It examines the applicable laws and international instruments on child marriage. The paper posits that child marriage remains prevalent especially in northern Nigeria because the practice of child marriage is accepted within the applicable customary law of the people. Despite the laudable provisions of the Child Rights Act of 2003, it has failed in tackling child marriage due mainly to the non-enactment of the law by northern States in Nigeria except Jigawa. Addressing this problem in Nigeria is crucial for the protection and realization of the child rights, especially the girl child. The paper concludes that early marriage as it pertains to marriageable age be made a fundamental right under chapter iv of the Constitution of the Federal Republic of Nigeria 1999 as amended and multi-faceted approaches through mass enlightenment and grassroot door-to-door campaign is necessary to tackle the menace of child marriage.
\end{abstract}

Keywords: Child marriage, unabated menace,Child Rights Act 2003,Constitutional provisions, marriageable age. DOI: $10.7176 / J L P G / 98-24$

Publication date:June 30th 2020

\section{Introduction}

By virtue of Article 1 of the Convention on the Rights of the Child (CRC) 1989, ${ }^{1}$ early marriage refers to the marriage of a child less than eighteen years of age. This type of marriage is also referred to as child marriage.

The Inter-African Committee (IAC) on Traditional Practices affecting the Health of Woman and Children states that early marriage is:

Any marriage carried out below the age of eighteen years, before the girl is

physically, physiologically and psychologically ready to shoulder the responsibilities of marriage and child bearing ${ }^{2}$.

In Nigeria, section 277 of the Child Rights $\mathrm{Act}^{3}$ passed into law in 2003 defines a child as a person who has not attained the age of eighteen years. However, according to Article 2 of Children and Young Persons Act of 1958 enacted in Eastern, Western and Northern Regions, a child means a person under the age of fourteen years, while young person means a person who has attained the age of fourteen years and is under the age of seventeen years:

Whereas the Matrimonial Causes $\operatorname{Act}^{4}$ (MCA) puts the age of maturity at 21.

The term "early marriage" refers to both formal and informal union where a girl cohabits with a man as if married before the age of eighteen. ${ }^{5}$ Section 21 CRA states that "No person under the age of 18 years is capable of contracting a valid marriage and accordingly a marriage so contracted is null and void and of no effect whatsoever."

The right to exercise a choice in marriage was recognized as a principle of law in Roman times as far as the eighteenth century and has long been established in international human rights instruments such as the Child Rights Act (CRA), Convention on the Rights of the Child (CRC) etcetera; yet many girls enter marriage without any chance of exercising their right to choose.

However, child marriage is one of the several forms of harmful practices imposed on the girl child and this is a gross violation of their rights. Its prominent feature is that it involves a child whom by definition in the convention on the Rights of the Child (CRC) is "a person below the age of 18". The devastating impacts of child marriage $e^{6}$ continues to be ignored in the developing world.Millions of child brides are denied access to health , education and economic opportunities,some of them just past puberty. Most of them are burdened with wives and

\footnotetext{
${ }^{1}$ It is to be noted that the Child Right Convention CRC has been ratified by all the States in America and even Somalia. Virtually every provision of the $\mathrm{CRC}$ is of some relevance to the issue of early marriage which is the focal point of this paper.

${ }^{2}$ The Inter-African Committee (IAC) on Traditional Practices Affecting the Health of Women and Children (1993) newsletter, December 2003 at 1 .

${ }^{3} 2003$ Cap C50 Laws of the Federation of Nigeria (LFN) 2004.

${ }^{4}$ cap. M7 Laws of the Federation of Nigeria 2004.

${ }^{5}$ United Nations International Children Emergence Fund (UNICEF).

${ }^{6}$ Early Marriage and Child Marriage are used interchangeably in this paper. They both suggest the same meaning.
} 
mothers ' roles and responsibilities, without adequate support, resources or capabilities. That is despite the numerous existence of international and regional human rights Conventions versus practice.

Addressing child marriage is a daunting but potential task requiring proactive legal multi - faceted strategic policies at the international, national, community level and strong political will on the part of government.

This paper in lieu of the above deals with six interrelated parts beginning with the introductory part. Part 2 discusses some literature on child marriage. Part 3 highlights the essential validity of marriage. It discusses the issue of age as it pertains to child marriage. Succinctly, part 4 examines the municipal laws such as the Constitution of the Federal Republic of Nigeria 1999 as amended, Marriage Act and international instruments such as The Universal Declaration of Human Rights (UDHR) 1948, Convention on the Rights of a Child (CRC), The Convention on the Consent of Marriage, Minimum Age for Marriage and Registration of Marriage 1962 which pertains to child marriage. Under part 5, mention is made on the limitations of early marriage on the rights of the Nigerian child. Some of the major limitations of child marriage on the rights of the Nigerian child emanated from the very stiff opposition from religious groups and traditionalist. ${ }^{1}$ The main opposition came from the northern States of Nigeria where islam is the predominant religion.Part 6 examines the need for socio-legal interventions in curbing child marriage by stating that laws alone won't end child marriage. In many instances, legislation is not implemented, since many local authorities are unwilling tosee themselves as intervening in family's private relations.Religious leaders and traditional rulers should play key roles by speaking out against child marriage and changing community attitudes. Part 7 concludes by stating that early marriage as it pertains to marriageable age be made a fundamental right under chapter iv of the Constitution of the Federal Republic of Nigeria 1999 as amended.

\section{Literature Review}

Onokah states ${ }^{2}$ that the Marriage Act does not specify any minimum age limit. Thus, she states that the absence of a common minimum age, even by implication, for marriage under customary law further highlights the flaws in the Marriage Act of 1914 in relation thereto. ${ }^{3}$ This author called for a reform of the Marriage Act in order to provide for a minimum age for statutory marriage. ${ }^{4}$ On his part, Nwogugu examines ${ }^{5}$ the types of marriage in Nigeria. The author also examines to a large extent the attitude of customary law to the marriage of a minor and the various legislative interventions by different regions in Nigeria in respect of the marriage of a minor under customary law. ${ }^{6}$

Gbadamosi points ${ }^{7}$ out that early marriage of girls undermines their rights as provided for under international treaties and municipal laws. He observes that despite the legislation aimed at combating early marriage, the practice still persists because the enforcement of the above laws has been weak. ${ }^{8}$ He however states that "... the Marriage Act provides that a marriage shall be void if either party is not of marriageage ". He proceeds to submit that the statutory provision is important to prevent the devastating consequences of child marriage. ${ }^{9}$ Nnadi discusses ${ }^{10}$ child marriage from a human rights perspective. Nigeria has a number of laws which are in contradistinction with the cultural practices of child marriages in the country; and despite the country being a signatory to several international treaties and conventions, yet, the rate of child marriages remains high. ${ }^{11}$ According to the author, child marriages are tolerated and justified based on two grounds. They are:

... the prevalence of customs and perceived religious reasons by families on the basis of the importance placed on virginity at the time of marriage; it was believed that child marriage will foreclose possibilities of sexual contact that would tarnish the family honour. Poverty was another reason for this practice.

It is noted that such marriages are celebrated in breach of a child's fundamental human rights as enshrined in the Constitution of the Federal Republic of Nigeria, 1999 (CFRN 1999). ${ }^{12}$

On the need to use international human rights instrument to protect the rights of victims or likely victims of forced marriages, Onuora-Oguno and Olayinka ${ }^{13}$ appraised the obligations of Nigeria under international human

\footnotetext{
${ }^{1}$ United States Department 2007 Country Reports on Human Rights Practices" in Nigeria, 11 ${ }^{\text {th }}$, March, 2008.

${ }^{2}$ Onokah, M.C. (2003) Family Law Ibadan: Spectrum Books Limited, 2003 at 124.

${ }^{3}$ Ibid.

${ }^{4}$ Ibid. at 125 .

${ }^{5}$ Nwogugu, E.I (2011) Family Law in Nigeria (Revised Edition) Ibadan: HEBN. Publishers Plc at 24.

${ }^{6}$ Ibid. at $60-63$.

${ }^{7}$ Gbadamosi, O. (2007) Reproductive Health and Rights (African Perspectives and Legal Issues in Nigeria) Benin-City: Ethiope Publishing Corporation at $290-291$

${ }^{8}$ Ibid. at 294.

${ }^{9}$ Ibid. at 113 .

${ }^{10}$ Nnadi I (2014) Early Marriage: A Gender" Based Violence and a Violation of Women's Human Rights in Nigeria", Journal of Politics and Law Vol. 7, No. 3 at 35

${ }^{11}$ Ibid.

${ }^{12}$ Sections. 33, 34, 35, 37, 38, 39, 42 and 45 of the CFRN 1999 as amended.

${ }^{13}$ Onuora-Oguno, A and Olayinka, A., (2015) Sexual Abuse and Child Marriage: Promise and Pathos of International Human Rights Treaties
} 
rights law to curb the prevalence of child marriages in Nigeria and a girl's right to be free from sexual abuse. They identified some legal challenges which confront the application of international treaties aimed at combating child marriages in Nigeria. ${ }^{1}$ These include the lack of a direct application of international treaties as provided for under section 12 of the CFRN 1999 as amended until they are fully domesticated by an Act of the National Assembly ${ }^{2}$; the status of such domesticated treaties among national laws; and the inability of about 12 States out of the 36 States of the Federation to domesticate the CRA 2003 which is an Act of the National Assembly consequent upon the implementation of the United Nations (UN) Convention on the Rights of the Child (CRC) $1989 .{ }^{3}$

Writing on the legality of child marriage, Fayokun notes that the northern part of Nigeria has a high rate of child marriages which are often rooted in the cultural and religious beliefs of the people. ${ }^{4}$ The author keenly observes that issues surrounding the legality or otherwise of child marriages in Nigeria are very controversial ${ }^{5}$ and there is a need to draw the lines between cultural and religious tolerance as enshrined by the CFRN 1999 pursuant to section 38 of the CFRN $1999^{6}$ and the need to protect the constitutional rights of victims of forced (child) marriages as guaranteed under section 45(1) of the CFRN 1999. ${ }^{7}$ Fayokun equally pointed out the current debate amongst Islamic scholars on the legality of child marriage within Islam noting that "... Islam mandates men and women to choose their partners voluntarily, and children are unable to do so." 8

Bayisenge highlights how early marriage is an impediment to a child's right to education, economic growth and personal development; ${ }^{9}$ thereby infringing on the human rights of the girl child. ${ }^{10}$ Bayisenge's article is, however, limited to the developmental challenge which early marriage poses to African countries with particular reference to its negative consequence on the girl child's education. Issues relating to the precarious position of the Nigerian child, denial of the right of free expression, life, survival, non-discrimination are not addressed. This study will seek to approach these issues from a human rights' perspective.

The different legal frameworks on child marriage is analysed by Rangita de Silva-de-Alwis. ${ }^{11}$ This author considers child marriage from a feminist perspective in relation to human rights. She prefers to approach the issue of child marriage using a rights-based approach which is considered a potent check-tool for child marriages. According to the author, international human rights law, constitutional law, laws on gender equality, amongst others are interrelated and could all be possibly employed to combat child marriage. In this respect, the author holds the view that the State and civil society must take responsibility for the incidences of child marriages, having failed to uphold its obligations under international law.

Megan Arthur et al ${ }^{12}$ reflected on the "legal protections against child marriage around the world." The authors note that despite the Beijing Declaration and Platform for Action in 1995 which kicked against childbearing at a tender age, negative health implications of child marriage, discrimination of the girl-child and encouraged governments all over the world to take steps to establish a minimum age of marriage, most child marriages still operate with parental consent. ${ }^{13}$

Bromley specifically discusses ${ }^{14}$ the nature, formalities and effect of marriage. The author argues that under English law if either party to a marriage is over the age of 16 but under the age of 18, certain persons are normally required to give their express consent to the marriage or are given a power to dissent from it. ${ }^{15}$ He notes that the purpose of this provision is to prevent minors from contracting unwise marriages. ${ }^{16}$ Cretney and Masson highlight ${ }^{17}$

in Safeguarding the Rights of the Girl Child in Nigeria. Child Abuse Research: A South African Journal Vol 16(2), 78 - 87.

${ }^{1}$ Ibid. at 81 .

${ }^{2}$ Registered Trustees of National Association of Community Health Practitioners of Nigeria v Medical and Health Workers Union of Nigeria [2008] 2 NWLR (Pt 1072) 575. In this case, the Supreme Court of Nigeria overturned the decision of the Court of Appeal by holding that the International Labour Convention does not have any legal force in Nigeria because it has not been domesticated.

${ }^{3}$ Onuora-Oguno and Olayinka, op.cit. at 81 .

${ }^{4}$ Fayokun, K.O., (2015) Legality of Child Marriage in Nigeria and Inhibitions against Realisation of Education Rights US-China Education Review B, Vol. 5 No. 7460 at 461.

${ }^{5}$ Ibid.

${ }^{6}$ Section 38 of the CFRN 1999 amended provides for the freedom of thought, conscience and religion.

${ }^{7}$ Section 45(1) of the CFRN 1999 as amended provides: "Nothing in sections 37, 38, 39, 40 and 41 of this Constitution shall invalidate any law that is reasonably justifiable in a democratic society (a) in the interest of defence, public safety, public order, public morality or public health; or (b) for the purpose of protecting the rights and freedom of other persons."

${ }^{8}$ Ibid.

9 Bayisenge J, Early Marriage as a Barrier to Girl's Education: A Developmental Challenge in Africa available at:<www.ifuw.org/fuwa/docs/Earlymarriage.pdf\&ved=0CA8QFjAA\&usg=AFQjCNHoNVrxGRe3LvOSL3cvnvq17Vxw $>$ accessed 27 May 2020 .

${ }^{10}$ Ibid at 10

${ }^{11}$ Rangita de Silva-de-Alwis (2008) Child Marriage and the Law: Legislative Reform Initiative Paper Series, (New York: UNICEF Division of Policy and Planning at $1-76$.

${ }^{12}$ Megan Arthur et al. (2014) Legal Protections against Child Marriage around the World. World Policy Analysis Center, MACHEquity at 3.

${ }^{13} \mathrm{Ibid}$. at 5 .

${ }^{14}$ Broomley, P.M Family Law (1981) London: $6^{\text {th }}$ ed., Butterworths at $16-18$.

15 Ibid. at 39.

16 Ibid.

${ }^{17}$ Cretney, S.M. and Masson, J.M., (1990) Principles of Family Law London: 5th ed. Sweet \& Maxwell at 34 
the issue of minimum age of marriage as one of the grounds for a void marriage where either party is under the age of 16. They observe that the attitude concerning the age below which marriage should not be permitted has been affected by change perceptions of the relevant social and economic issues. At one time, parentally approved marriage between a couple who had attained the age of puberty may well have seemed unobjectionable: age as such was not important. Then informed opinion became concerned with problems of child sexual abuse and prostitution, which were thought to be related to the age at which marriage was permitted. ${ }^{1}$

In the same vein, Tonwe and $\mathrm{Edu}^{2}$ examined the concept of marriage under customary law. The learned authors state that marriage is not easy to define due to the fact that there are different forms of marriage depending on the culture of each society. The legal requirements of customary law marriage which include betrothal, capacity of the parties to the marriage, consent, marriage consideration, solemnization of marriage and consummation were discussed by the authors. There is no prescribed age limit under customary law for a person to marry, hence the rampant incidence of forced marriage under customary law.

On his part, Adegbite ${ }^{3}$ examined marriage under the Act, divorce, child custody, matrimonial property and inheritance, maintenance and alimony, bigamy, paternity, adoption, customary law marriage and divorce and Islamic law marriage and divorce. With respect to age of marriage, the author states that a girl attains marriageable age as soon as she attains puberty and start experiencing her menstruation. Sagay ${ }^{4}$ appraises the formal and essential validity of statutory marriage. He discusses the issues of age and consent under the essential requirements of a valid statutory marriage. He stated that marriageable age is neither defined in the Matrimonial Causes Act nor in the Marriage Act and that the argument that in the absence of such definition, Nigeria has reverted to the common law ages of 14 years for men and 12 for girls is utterly unconvincing.

\section{Essential Validity of Marriage}

The parties to a marriage under the Marriage Act (MA) must possess the necessary capacity contained in the statute. Under this head, we shall consider essentially the issue of age since it has direct relevance to this paper.

\subsection{Age}

A party to a marriage must not be an infant. She must be matured enough for marriage. The Marriage Act does not provide any mandatory minimum age of marriage. The Matrimonial Causes Act (MCA) makes a marriage void "if the parties are not of marriageable age" but it does not define the term marriageable age. The absence of a legal minimum age for marriage is a contributory factor to the incidence of child marriage and its attendant problems.

It must be noted that some people are totally incapable of marrying because they have no capacity. They include infants, that is, children below the age of 18 years and mentally ill persons. The Marriage Act (MA) merely states that unless a party is a widow or widower, there is need to obtain the written consent of either of the parents or the guardian, where such a party is under the age of 21 years.

The Marriage Act further provides that:

Whoever knowing that the written consent required by the Act has not been obtained, shall marry or assist or procure any other persons to marry a minor under the age of twenty-one years; not being a widow or widower, shall be liable to imprisonment for two years. ${ }^{5}$

Onokah has drawn inference from the above provision thus:

The inference to be drawn from that provision is that a person who is above the age of twenty-one need not comply with the requirement for obtaining consent, and that a person who is under twenty-one and hence "a minor", but who has become a widow or widower need also not comply with the requirement for obtaining consent. ${ }^{6}$

It is submitted that even the Matrimonial Causes Act (MCA) which should have filled the gap, also failed in this respect. It merely provides for the invalidation of a marriage where "either of the parties is not of marriageable age". 7

It is observed that both the Marriage Act (MA) and the Matrimonial Causes Act, (MCA) ${ }^{8}$ seem to encourage like the indigenous customary law, the obnoxious practice of early marriage.

In the absence of a statutory definition of age of marriage, Nwogugu has suggested that recourse be had to

\footnotetext{
${ }^{1}$ Ibid. at 44 .

${ }^{2}$ Tonwe, S.O and Edu O.K, (2007) Customary Law in Nigeria Renaissance Law Publishers Limited at 151-161.

${ }^{3}$ Adegbite K (2017) What The Law Says About Marriage And Divorce: Answer to All Your Questions Global Image Books \& Publishers at 145.

${ }^{4}$ Sagay, I (1999) Nigerian Family Law: Principles, Cases, Statutes and Commentaries Lagos: Malthouse Press Limited at 48-103.

${ }^{5}$ See section 48 of the Marriage Act.

${ }^{6}$ Onokah op.cit.

${ }^{7}$ Section 3(1)(e) Matrimonial Causes Act.

${ }^{8}$ As both were silent on marriageable age.
} 
the common law rule on the subject. The learned author states that:

Part of the received English Law in Nigeria is the common law of England.Under common law, a valid marriage may be contracted if the parties have reached the age of puberty fourteen years for a boy and twelve years for a girl. ${ }^{1}$

We submit without equivocation that recourse to the common law provisions as suggested by the learned author will further give a voice and validity to the prevalence of early marriage in Nigeria which this paper is set to address. It should be noted that at present in England, there has been a shift from the common law position. As a result of the change of attitude by the Bench and the legislature. The Age of Marriage Act was passed in 1929, sections ${ }^{2}$ 1-7 of the Act effected two changes in the law. First, it enacted that a valid marriage could not be contracted unless both parties had reached the age of 16 and secondly any marriage to which either party was under this age was made void and not voidable as previously.

It is further submitted that the absence of a common minimum age, even by implication, for marriage under customary law further highlights the flaws in the Marriage Act in relation thereto. ${ }^{3}$

The failure on the part of the draftsman of the Marriage Act (MA) to provide for a minimum age for statutory marriage leaves much to be desired of that statute and therefore calls for a reform of the Marriage Act. ${ }^{4}$

Succinctly, the issue of early marriage is prevalent in customary law marriage in Nigeria. Most systems of customary law in Nigeria do not prescribe any age for the solemnization of customary law marriage. This lacuna in the rule of customary law has to a large extent encouraged a high incidence of child marriage, with all its attendant evils.

Thus, the system of customary marriage sets a flexible minimum age. In some parts of the country, legislation has set the minimum age for marriage under customary law. The age of marriage under customary law is governed by the Age of Marriage Law 1956 (later referred to as ' the law') ${ }^{5}$. in the five Eastern States of Nigeria. According to section 4(1) of the Act, is an offence punishable by six months ' imprisonment or a fine of two hundred naira for any person to ask, receive or obtain any property or benefit of any kind for himself or for any other person on account of marriage which is null under the law. Nwogugu submitted that, with the exception of cases before the courts, there was much evidence that the prohibition of the marriage age law was not observed in many parts of the five Eastern States. ${ }^{6}$

Further more, in four Native Authority Areas in three of the northern states of Nigeria, Biu (Borno State), Idoma and Tiv (Benue State), and Borgu (Kwara State), the marriageable age for girls has been fixed by the various sections of Native Marriage Law and custom orders made in respect of these areas. The following ages for girls have been prescribed for the respective areas: Biu is 14 years: $;{ }^{7}$ Idoma is 12 years $;{ }^{8}$ Tiv is age of puberty; ${ }^{9}$ and Borgu is 13 years. ${ }^{10}$ In Borgu and Idoma, any person who marries a girl below the age indicated and the father or guardian of such a girl who permits such a marriage is guilty of an offence punishable with a fine of $\# 100$ or six months ' imprisonment or both. ${ }^{11}$

Emanating from the foregoing laws setting out minimum age requirements for marriage under the various regions of Nigeria, ${ }^{12}$ our contention is that the various laws have not been able to take into consideration the resultant effect in which such marriage at the ages of thirteen, fourteen and sixteen would have on the life of a child. Marriages at such ages under our customary laws in Nigeria at this modern time negates our commitments to uphold international human rights norms which address the issue of early marriage and also runs in contradistinction with the provisions of the Child Rights Act which is geared towards the protection of the rights of the Nigerian girl child.

The sad case of Wasila Umaru is very apposite here in further alluding to the appaling rule of customary law marriage pertaining to early marriage. Can it be said that it was Wasila Tasiu, a 14-year-old bride, who was giving

\footnotetext{
${ }^{1}$ Nwogugu op.cit. The learned author stated that "suggestions that Nigeria has reverted to the common law ages of 14 for men and 12 for girls are utterly unconvincing."

${ }^{2}$ Now re-enacted in section 2 of the Marriage Act 1949.

${ }^{3}$ Onokah, loc. cit.

${ }^{4}$ Onokah, op. cit 125 .

${ }^{5}$ Cap 6 Laws of Eastern Nigeria, 1963; This law does not, as has been erroneously construed in some quarters, deal with marriages under the Marriage Act; Section 2 of the law clearly states that 'marriage' in the law means a marriage according to customary law.

${ }^{6}$ See Nwogugu, op. cit. at 45.

${ }^{7}$ Section 1(a) of the Native Authority (Declaration of Biu Native Marriage Law and Custom) Order 1964.

${ }^{8}$ Section 2(1)(a) of the Native Authority (Declaration of Idoma Native Marriage Law and Custom) Order 1956

${ }^{9}$ Section 2(1)(a) of the Native Authority (Declaration of Tiv Native Marriage Law and Custom) Order 1955

${ }^{10}$ Section 2(1)(a) at the Native Authority (Declaration of Borgu Native Marriage Law and Custom) Order 1961.

${ }^{11}$ Section 2(2) of the Native Authority (Declaration of Borgu Native Marriage Law and Custom) Order 1961 and the Native Authority (Declaration of Idoma Native Marriage Law and Custom) Order 1959, see generally, Nwogugu, loc. cit.

${ }^{12}$ It is noted that there is no corresponding legislation in the Western States relating to the age of marriage under Yoruba customary law. The Marriage, Divorce and Custody of Children Adoptive Bye-Laws Order, 1958 of the Western States, Western Region L.N 456 of 1958 , merely provided under section 7 that in a petition for divorce, the court should take into consideration the fact that the parties were betrothed under marriageable age. Thus, the law stipulated no minimum age for marriage under Yoruba customary law.
} 
her consent to marry Sani Umar, a 35-year-old man, in the city of Kano when that marriage purportedly took place? This, she later denied as against her wishes and consent and in expressing her utter disgust, killed her husband and his friends through food poisoning? Wasila cannot sue or be sued except through a next friend, a guardian ad litem, or a person in- loco-parentis. She cannot vote at the general elections nor obtain a driving licence.

\section{Municipal Laws and International Instruments on Early Marriage}

It has become universally recognized and accepted principle that individuals possess certain definite political, civil, economic and social rights which governments have the duty and responsibility of protecting and enforcing. The concept of human rights cannot be taken away from human beings because these are rights to which we are entitled because we are humans. As such, every person is entitled to such rights without hindrance except in circumstances excusable by law.

In their long history of addressing women's human rights, ${ }^{1}$ the United Nations and the African Union have made a considerable progress in the promotion and protection of human rights across the globe. It is conceded that a number of important gaps remain to be addressed as there are now manifestations of the violation of women's human rights. ${ }^{2}$

One of such gaps, is women's human right to equality and to choose a partner in marriage. ${ }^{3}$

In dealing with this, an examination of the major provisions on human rights under municipal and international instruments as it pertains to early marriage is discussed.

\subsection{Municipal Laws}

Applicable municipal laws to child marriage in Nigeria are:

i. The Nigerian Constitution of 1999 as amended.

ii. Child Rights Act

iii Marriage Act

\subsubsection{The Constitution}

There is no specific provision in the Nigerian Constitution which deals with marriageable age and the explicit protection of the Nigerian child. There is therefore a compelling need to include a provision of this in the Constitution. Yet, the 1999 constitution is the grundnorm, supreme for the protection of the rights of all citizens, including children.

The 1999 Constitution makes provision for Fundamental Objectives and Directive Principles of State Policy of Nigeria contained in chapter two. These fundamental rights are contained in sections 33-46 of chapter iv of the 1999 Constitution. These include: the right to life (section 33), the right to dignity of the human person (section 34 ), the right to personal liberty (section 35), the right to fair-hearing (sections 35), the right to privacy and family life (section 37), the right to freedom of thought, conscience and religion (section 38), the right to freedom of expression and the press (section 39), the right to freedom of movement (section 41), the right to freedom from discrimination (section 41).

The 1999 Constitution of the Federal Republic of Nigeria has provided for enforcement of these rights by the courts through the fundamental rights (Enforcement Procedure) Rule. ${ }^{4}$

It can be argued that Nigeria is not abiding to international legal obligations by virtue of section 61 of part 1 of the second schedule to the 1999 constitution $^{5}$ which which eliminates any legal limitations on Islamic and customary marriages.

Child marriage persist endlessly in Nigeria because two seemingly insignificant loopholes in the Constitution of the Federal Republic of Nigeria (CFRN) 1999 as amended are fingered as the legal obstacles against the eradication of child marriage. The first is section 29(4), while the other is item 61, part 1 of the second schedule to the Constitution. Section 29(1) permits a citizen of Nigeria of full age who wishes to renounce his citizenship to make a declaration in prescribed manner. Section 29(4) states that "for the purpose of subsection (1) of this section: (a) "Full age" means the age of eighteen (18) years and above; and (b) Any woman who is married shall be deemed to be of full age (Federal Republic of Nigeria, 1999 chapter III). With this understanding of our Constitution since 1979, a senate committee in July, 2014 voted to remove the archaic "part (b)" of the subsection, "thereby supporting the fight against forced marriage and paedophilia". However, after a heavy lobbying, senatorSani Ahmed Yerima (the same man who at 49 had married a 13 years-old Egyptian girl) persuaded the senate to reverse its decision, thereby retaining the obnoxious subsection and re-enacting a legal ground for child marriage. The second loophole is tucked away in item 61 , part 1 , of the second schedule to the Constitution. In the "exclusive

\footnotetext{
${ }^{1}$ It should be noted that reference to women or women's right in this work also implies girl or girls' rights.

${ }^{2}$ Muftau, R., (2016) An Appraisal of the Legal Rights of Women in Nigeria Journal of Law, Policy and Globalization, vol. 52, 69 at 69.

${ }^{3}$ Onuora and Olayinka op.cit 78 at 80 .

${ }^{4}$ Section 1 of the Preamble to the Constitution of the Federal Republic of Nigeria, 1999 as amended.

${ }^{5}$ Section 61 'the formation, annulment and dissolution of marriages other than marriages under islamic law and customary law including matrimonial causes relating thereto..
} 
legislative list" of the Federal Government is item 61. The formation, annulment and dissolution of marriage other than marriage under islamic law and customary law including matrimonial causes relating thereto (Federal Republic of Nigeria, 1999 chapter V). It effectively takes marriage under islamic and customary law out of the federal legislative competence. In other words, though the whole country is bound by federal law, in the strict sense, the laws of the National Assembly have no effect on the formation, amendment and and dissolution of marriage in accordance with islamic law and customary law, including matrimonial causes relating thereto.

\subsubsection{Child Rights Act}

The Child ${ }^{1}$ Rights Act (CRA) is a comprehensive law that provides for the welfare and determination of all civil and criminal proceedings relating to the Nigerian child. The CRA is a law which incorporates the provisions of several separate earlier laws ${ }^{2}$ relating to children. The CRA of 2003 sets the minimum age of marriage at 18 , but as of March 2013, only 23 of Nigeria's 36 states have adopted the Act save only Jigawa from the northern State. As a result, State laws on the minimum age of marriage vary; in southern Nigeria, the minimum age of marriage is between 18 and 21 years of age, depending on the region. In the North, it ranges from 12 to 15 years.

No person under the age of 18 is capable of contracting a valid ${ }^{3}$ marriage and accordingly a marriage so contracted is null and void with no legal effect whatsoever.

The CRA deals with so many issues and it is divided into 24 parts, however only the part applicable to this paper would be highlighted. Some laudable provisions of the CRA pertaining to child marriage are adumbrated as follows:

1. The CRA prohibits prohibits marriage to children. A person under the age of 18 is unable to enter into a valid marriage and is null and void. ${ }^{4}$ where that marriage is contracted void. ${ }^{5}$

2. A parent, guardian or any other care-giver cannot betroth a child in contravention of this section, as such betrothal will be null and void. ${ }^{6}$

3. The Act states clearly the category of persons contemplated by this provisions, that is, a person who marries a child, to whom a child is betrothed, promotes the marriage of a child or who betroths a child. ${ }^{7}$

4. The Act makes it an offence liable on conviction to a fine of $\# 500,000$ or imprisonment for a term of five years or both. ${ }^{8}$

\subsubsection{Marriage Act (MA)}

In its commencement page, the Marriage Act provides that it is an Act to make provisions for celebration of marriages. Section 1 of the MA states that this Act may be cited as the Marriage Act. It goes further to provide for the preliminaries to marriage. Among the requirements under preliminaries is notice of marriage. Section 18 of the MA talks of consent to marriage in certain cases and in section 21 celebration of marriage is discussed. The MA goes further to provide for provisions on Registry and Evidence of Marriages. Invalid marriages are provided for in section 33 of the MA. The MA also provides for offences and penalties relating to statutory marriages. The Act provides for validity of foreign marriages. From the provisions of the MA, statutory marriages must comply with its provisions, otherwise such marriage would be declared invalid.

The MA is also silent on the prescribed marriageable age for intending couple as this is not expressly provided for under the MA. This lacuna has made it difficult to effectively sanction perpetrators of child marriage. The MA merely states that unless a party is a widow or widower, there is need to obtain the written consent of either of the parents or guardian where such a party is under the age of 21 years. Section 3(1) states that "marriage between or in respect of persons either of whom is under the age of sixteen shall be void." Section 18 requires a party to an intended marriage who is below 21 years to annex a written consent of his parents or guardian to his/her affidavit before a license is issued.

\subsection{International Instruments}

International instruments such as The Universal Declaration of Human Rights (UDHR), Convention on the Rights of a Child (CRC), The Convention on the Consent of Marriage, Minimum Age for Marriage and Registration of Marriage 1962, International Convention on Economic, Social and Cultural Rights (ICESCR) 1976 as they pertain to early marriage will be adumbrated on.

\subsubsection{The Universal Declaration of Human Rights (UDHR) 1948}

${ }^{1}$ Child Rights Act, (2003)

${ }^{2}$ CFRN 1999 as amended, African Charter on the Rights and Welfare of a Child (1990) (ACRWC) Convention on the Rights of the Child (1990) etcetera.

${ }^{3}$ Article 21, CRA (2003).

${ }^{4}$ Section 21.CRA, According to some scholars, the rationale for prohibition of child marriage is as a result of incessant cases of $v v f$, vesico vagina fistula, in some parts of the country where early child marriages are common. Also, such children below the age of 18 years may not necessarily be fit mentally and psychologically to bear the burden of motherhood or parental responsibilities towards children.

${ }^{5}$ Section 21.CRA, According to some scholars, the rationale for prohibition of child marriage is as a result of incessant cases of $v v f$, vesico vagina fistula, in some parts of the country where early child marriages are common. Also, such children below the age of 18 years may not necessarily be fit mentally and psychologically to bear the burden of motherhood or parental responsibilities towards children.

${ }^{6}$ Section 22(1) CRA.

${ }^{7}$ Ibid

${ }^{8}$ Ibid. 
The UDHR which was adopted in 1948 also emphasise that all men and women without differentiation on the basis of sex are equally entitled to their rights as contained in the declaration. ${ }^{1}$ The rights of all persons who have attained a marriageable age to marry and found a family is recognized in Article 16(1) of the UDHR. Article 16(2) of the UDHR requires the voluntary total consent of intending spouses before a marriage is contracted. Hence, the right to choose a partner in marriage, to make a decision on whether to get married or to decide when to get married is recognized as a human right by the UDHR. ${ }^{2}$ Thus, it is the human right of all persons, whether male or female to enter into consensual marriage contract. ${ }^{3}$

It is submitted that not withstanding the fact that the UDHR explicitly declares that the voluntary and total consent of intending spouses to enter into marriage is a human right, not everybody enjoys the right to choose a marriage partner. It is suggested for instance, that in the traditional Nigerian family, the right of young persons especially a female child to choose a marriage partner is not exclusive. In most cases, this right is made subject to parental consent even in cases where the female child has come of age and could independently make her choice.

In a bid to protect their children and to ensure that an intending marriage is in the best interest of their children, parents are often seen making a choice of marriage partners. The wish of parents to have their children in a marriage with socio-economic stability; to prevent their children from making a bad choice; the obligation which parents naturally think they owe their children, ${ }^{4}$ to find suitable marriage partner for them, the need to strengthen the bound of friendship and or political ties between families, to secure or add to the family fortune; where there is no family fortune, the need to be emancipated from social slavery and poverty are some of the reasons why parents deprive their children their human rights to choose a marriage partner.

In doing this, parents do not only introduce and encourage partners, but they are often seen forcing their children into marriages.In Nigeria, ,several research on the incidence of child marriages has been carried out.In 1999, the Nigerian Demographic and Health Survey (NDHS) ${ }^{5}$ reported that 26.5 percent couples there is an age difference of 15 or more years between husband and wife. To them as parents they are often seen forcing children into marriages consciously or unconsciously. Nevertheless, parents feel they are discharging their parental obligations on the basis of the care and love they have for their children. They do not perceive it as a violation of their children's human right to choose a marriage partner freely and without any form of duress or undue influence. ${ }^{6}$

\subsubsection{Convention on the Rights of a Child (CRC)}

Convention on the rights of the child is one of the most important international conventions that covers the context of children's rights and recognizes that children are entitled to human rights in their own right. ${ }^{7}$ Nigeria became a signatory to this convention on the June 261990 and ratified same on the April 19 1991. The CRC takes on a general approach and does not specifically prohibit the practice of child marriage. However, it has four governing pillars that can be used and interpreted in order to address the human rights violations that occur through the practice of child marriage. These four pillars include the right against non-discrimination, ${ }^{8}$ the best interest of a child, ${ }^{9}$ the right to life $^{10}$ and the right to participation. ${ }^{11}$

Article 2 provides for the principle of non-discrimination on the grounds of inter alia, sex and age. ${ }^{12}$ Taking into account the negative effect that child marriage has on the girl child, Article 2 can be interpreted to protect the girl child against child marriage because it is a discriminatory harmful practice that disproportionately affects young girls. However, where State parties fail to address harmful practices in accordance with the protection embedded under this conventions the subsequent result is the neglect of the experiences, interests, needs and rights of which the girl child is entitled .13

The committee on the rights of the child has in its concluding observations expressed concern about the lack of commitment from State parties towards ensuring the effective implementation of the principle of non discrimination in order to address the widespread practice of child marriage.14Another fundamental principle in

\footnotetext{
${ }^{1}$ Ashiru, M.O.A (2007) Gender Discrimination in the Division of Property on Divorce in Nigeria Journal of African Law vol 51. No. 2316 at 325-326.

${ }^{2}$ Onuora and Olayinka, op. cit 79

${ }^{3}$ Ibid.

${ }^{4}$ Part 1: CRA- Best Interest of a child is paramount consideration in all actions including choice of a marriage partner.

${ }^{5}$ Children's and Women's Rights in Nigeria: A Wake-up call, situation Assessment and Analysis 2001 (National Planning Commission, Abuja and UNICEF 2001) at 200.

${ }^{6}$ See Ciniblak,K.L. Partner Choice, Arranged and Forced in the Dutch Multicultural Society <www.movies.ni/huweliksdang $>$ accessed 24 May 2020 .

${ }^{7}$ UN General Assembly, Convention of the Rights of the Child, 20 November 1989, United Nations, Treaty Series, vol. 1577 at 3.

${ }^{8}$ UN General Assembly, Convention on the Rights of the Child 1989, Article 2

${ }^{9}$ Ibid, Article 3.

${ }^{10}$ Ibid, Article 6

11 Ibid Article 12

${ }^{12}$ Ibid Article 2.

${ }^{13}$ UN General Assembly, Convention on the Rights of the Child 1989, Article 3.

${ }^{14}$ UN Committee on the Rights of the Child (CRC), UN Committee on the Rights of the Child: Concluding Observations: Vanuatu (10/11/ 1999, $\mathrm{CRC} / \mathrm{C} / 15 /$ Add.111)
} 
children's rights law is "the best interest of the child". 1 The term takes into account the deliberation that courts as the upper guardians of minors and children must undertake when deciding what type of services, actions and orders will best serve a child as well as who is best suited to take care of a child.2

Their relative immaturity that is young children depends on responsible authorities to evaluate and represent their rights and best interests with regard to decisions and actions affecting their

well-being, taking into account their own views and evolving capacities. What is clear is that there is a duty of care placed on responsible authorities to always prioritize the best interest of the child.

Regarding the issue of child marriage, it is arguable that the best interests of a child as a substantive principle requires the court to always prioritize the best interests of the child against the interests of the other parties involved when faced with child marriage cases. The principle of best interests also appears under Article 18 of the Convention of the Rights of the Child. For example, both parents have a shared responsibility of bringing up their children and taking decisions that are in the best interests of the child. This principle can be used to guard against gender-based decisions that parents make which are influenced by social, economic and cultural factors. This principle must be interpreted in consideration with the convention as a whole. This means that the best interest of a child principle should be at the centre of all actions, measures and strategies against the practice of child marriage. ${ }^{3}$

The right to life, survival and development refers to the child's inherent right to life and state parties have the duty to ensure the maximum extent possible for the survival and development of the child. ${ }^{4}$ General comment No 5 states that this principle must be interpreted broadly and holistically, encompassing the physical, mental, spiritual, moral, psychological and social development. ${ }^{5}$ According to the convention on the rights of the child committee, promoting the right to life, survival and development is however unduly threatened by the difficult socio-economic realities in some countries. ${ }^{6}$ State parties should ensure that the girl child's right to life, survival and development is not violated through harmful practices such as child marriage which has a direct negative effect on bringing the period of childhood to a premature end.

Lastly, Article 12 provides for the principle of participation by emphasizing the importance of children's participation in decisions and actions which affect them. ${ }^{7}$ As a procedural right, it allows children to act in order to protect and promote the realization of other rights that they are entitled to. ${ }^{8}$

In light of the general elements that constitute legal marriage as reflected in international conventions that have been discussed, and also the definition of a child, the principle of participation can be linked to the requirement of free and full consent. A girl cannot give free and full consent based on the mere fact that she is a child. The assumption that follows is that her parents or guardians provide for consent on her behalf. This infringes upon the girl child's right to participation because she is excluded from the decision-making process on a matter that directly affects her wellbeing and violates the rights she is entitled to as a child.

\subsubsection{The Convention on the Consent of Marriage, Minimum Age for Marriage and Registration of Marriage 1962}

This convention was ratified by the United Nations General Assembly on the November $171962 .{ }^{9}$ It entered into force on the December 9 1964. This is a vital instrument under international law. It specifically deals with issues of the human right of a person to enjoy the total freedom to choose a marriage partner. It discourages child marriages and the betrothal of young girls. Of particular relevance is the need for State parties to take steps in abolishing customs and ancient marriages that are inconsistent with the principles of human rights as established in the United Nations Charter and the Universal declaration of Human Rights. ${ }^{10}$

Taking into account the issue of child marriage, Warner observed that 'special vulnerabilities of children, whose consent can be easily coerced or unduly influenced by adults has not been captured in a number of conventions. ${ }^{11}$ However, the marriage convention places an obligation on parties to take legislative action to specify a minimum age for marriage and it explicitly states that a marriage that is entered by any person under this age is not legal. ${ }^{12}$

\subsubsection{International Convention on Economic, Social and Cultural Rights (ICESCR) 1976.}

\footnotetext{
${ }^{1}$ Ibid.

${ }^{2}$ Child Welfare Information Gateway, Determining the Best Interest of the Child (State Statutes, November 2012 ) at 2.

${ }^{3}$ Ibid.

${ }^{4}$ UN General Assembly, Convention on the Rights of the Child 1989, Article 6.

${ }^{5}$ Ibid, Article 3.

${ }^{6}$ Committee on the Rights of the Child, 'Consideration of Reports Submitted by States Parties under Article 44 of the Constitution' (concluding observations of the Committee on the Rights of the Child: Kanya, 2001) para 28.

${ }^{7}$ UN General Assembly, Convention on the Rights of the Child 1989, Article 12.

${ }^{8}$ Ibid.

${ }^{9}$ See General Assembly Resolution 1763 A(17).

${ }^{10}$ See the preamble to the Convention on Consent to Marriage Age for Marriage and Registration of Marriage 1964

${ }^{11}$ Elizabeth W (2004) Behind the Wedding Veil; Child Marriage as a Form of Trafficking in Girls, vol. 12 No. 2, American University Journal of Gender Social Policy and the Law at 247.

${ }^{12}$ UN General Assembly, Convention on Consent to Marriage, Minimum Age for Marriage and Registration of Marriages, Article 2.
} 
The ICESCR was made in accordance with the principles stated in the Universal Declaration of Human Right (UDHR). Thus, in recognition of the rights to the dignity of the human person which is founded on the principles of justice and freedom and the need to guarantee a society where human beings shall enjoy their human rights and be free from fear in the realization of those rights. ${ }^{1}$ The ICESCR was adopted in 1966 but came into force on the January 3 1976. The ICESCR prohibits discrimination on the basis of sex and states that women and men are equally entitled to the enjoyment of the right which are contained in the treaty.

The ICESCR guarantees amongst others the right to health, the right to work, the right to an adequate standard of living, the right to education and the right to marry, family, maternity and child protection.

Article 10(1) of the ICESCR re-emphasizes the need for marriage to be contracted with the voluntary consent of intending spouses. This also includes the voluntary consent of intending spouses, including the human right of a person to choose whom he or she wants to marry and the right not to be forced into any marriage which contravenes the dignity of the human person.

\subsubsection{International Convention on Civil and Political Rights (ICCPR)}

The International Convention on Civil and Political Rights guarantees, among other rights, the right to life, freedom from torture, freedom from slavery, the right to liberty and security of the person, rights relating to due process in criminal and legal proceedings, equality before the law, freedom of movement, freedom of thought, conscience and religion, freedom of assertion, association, right relating to family life and children, citizenship rights and political participation and the rights to minority groups of their culture, religion and language.

Article 3 of the ICCPR makes it obligatory on the part of the State parties to ensure that men and women enjoy equal rights as provided by covenant. It goes further to provide that no person shall be subjected to torture, inhuman or degrading treatment ${ }^{2}$ nor shall any person be held in slavery. ${ }^{3}$ The family as a component of the larger society is protected by the society and the State. ${ }^{4}$ Hence, Article 23(2) recognizes the right of all persons of marriageable age; whether female or male to marry and found a family. Although, the convention does not define the term "marriageable age". It proceeded in Article 23(3) to categorically state that a marriage shall not be contracted in the absence of the voluntary and total consent of the intending spouses. It is submitted that any marriage which lacks the "free and full consent" of the intending spouses cannot be said to be a marriage properly so-called and violates the human rights of the party whose "free and full consent was lacking". ${ }^{5}$ Where this right is violated, the spouse is most likely to be held in slavery that is against her will of such marriage.

\subsubsection{The Convention of the Elimination of all Forms of Discrimination Against Women (CEDAW) 1981}

The United Nations having recognized that discrimination against women ${ }^{6}$ is an offence against the dignity of woman made it an obligation under international human rights law in 1967 for countries to abolish native laws, custom and traditional practices which discriminate against women and to create adequate legal protection for equal rights of all persons. This was by virtue of an adoption of the United Nations Declaration on the Elimination of Discrimination Against Women. This was later on followed in 1979 with an adoption of the Convention on the Elimination of all Forms of Discrimination Against Women (CEDAW) by the United Nations General Assembly. The CEDAW preamble states that despite extensive instruments on human rights which abhor discrimination and encourages the equality of sexes, women still find it very difficult to enjoy equal rights with men in the society. In laying out the obligation of the States to achieve substantive equality and to eschew all forms of discrimination, CEDAW articulates the nature and meaning of sex-based discrimination.

Discrimination against women has been defined as any act of distinction, restriction or exclusion of women which is capable of infringing or violating the rights of women to enjoy their fundamental rights and deprive them of the right to equality with men. ${ }^{7}$

Sixteen articles of the CEDAW makes provision for the specific obligations of State parties to eliminate all forms of discrimination against women in political, social, economic and cultural fields. The convention deals with civil and political rights.

These include the right to vote, to public participation, the right to citizenship which include the right to acquisition, change and retention of one's nationality, equal protection of law, and economic, social and cultural rights which include the rights to education, work, health, marriage and family relations etcetera.

Of particular importance is Article 16 of the CEDAW which encourage States to take all appropriate measures in eliminating discrimination against women in relation to marriage and family matters. It emphasize that men and

\footnotetext{
${ }^{1}$ Article. 26 of the ICCPR 1976.

${ }^{2}$ Article. 7 of the ICCPR 1976

${ }^{3}$ Article 8 of the ICCPR 1976.

${ }^{4}$ Article. 23(1) of the ICCPR 1976

${ }^{5}$ See sections 3 and 34 of the Matrimonial Causes Act cap. M7 Laws of the Federation of Nigeria 2004.

${ }^{6}$ Peters D., (2000) The Domestication of International Human Rights Instrument, and Constitutional Litigation in Nigeria Netherlands Quarterly of Human Rights, vol. 18(3), 357 at 373.

${ }^{7}$ Article 1 of the CEDAW defines discrimination as "... any distinction, exclusion or restriction made on the basis of sex which has the effect or purpose of impairing the recognition, enjoyment or exercise by women, irrespective of their marital status, on the basis of equality of men and women, of human rights and fundamental freedoms in the political, economic, social, cultural, civil or any other field."
} 
women have equal rights to contract marriages. ${ }^{1}$ It also recognizes the right of a person to freely choose a marriage partner and contract a marriage only in cases where he or she has freely given his or her full consent. It further recognizes the equal rights and responsibilities of men and women during marriage and at its dissolution.

Article 16(2) of the CEDAW specifically provides that child betrothal and child marriage shall not be recognized in law and State parties must take all necessary actions to ensure that their national laws indicates a minimum age for marriage and make marriage registration compulsory in an official registry.

Through appropriate legislations we can ensure that the legal rights of women are protected and that discriminatory actions, customs and practices and laws, etcetera are prohibited, modified and abolished. State parties could eliminate discrimination. ${ }^{2}$

Thus, in achieving the equal status of men and women in the society, there is a need for State parties to take positive actions in order to improve the status of women in the society. ${ }^{3}$

\section{Limitations of Early Marriage on the Rights of the Nigerian Child}

Government and international community's engagements and commitments should ensure the supporting and enforcing legislation to increase the minimum age of marriage for girls to 18, providing equal access to quality primary and secondary education for girls and create social, economic and civic opportunities for girls and young women.

It is however noted that in some communities in Nigeria, law has not shielded its eyes to the possibility of an abuse of its power which parents have via the customary marriage of their daughters. To check any abuse of such power by parents who are adamant. Section 5 of the Western Region ${ }^{4}$ Marriage, Divorce and Custody of children Adoptive Bye-Laws Order 1958, provides that: when any parent or guardian of a bride refuses his or her consent to a marriage or refuse to accept his or her own share of the dowry, the bride, if she is eighteen years of age or above and the bridegroom jointly may institute legal proceedings in a competent court against the parent or guardian to show cause why he or she should refuse consent or to accept his opinion that no sufficient cause has been shown, it shall order that the marriage may proceed without the consent of the parents.

In these districts which have adopted this bye-law, there is therefore protection against parental veto. But a flaw in this lies its lack of provision for the court to order the erring father to formally receive the 'bride-price' and thereafter perform the handing over ceremony. It is however noted that the court has not hesitated to nullify a marriage where bride-price was received by the father of the bride without the consent of the bride. This was demonstrated in the case of Osawonyi v Osawonyi ${ }^{5}$ where the husband, Osawonyi, petitioned for nullity of his marriage to Mercy under the Act on the ground that before the said statutory marriage Mercy was already married under Benin native law and custom to Patrick Guobadia and that the marriage was still subsisting. Mercy successfully claimed that there could not have been any marriage between her and Patrick Guobadia as her consent to the marriage with him was not obtained before or after her father accepted the "dowry" from Patrick. The Supreme Court held that under Benin native law and custom, a daughter could not be married off to a man by her parent without her consent and that "unless there is cohabitation as well, payment of dowry alone does not constitute marriage under such Benin native law and custom.

It is also observed that the required age of "eighteen years and above" in the Bye-law suggests that the customary law in that region takes cognizance of the fact that the age of 18, is the age of maturity for marriage where the girl child is capable of giving her consent. ${ }^{6}$ It is this age that this paper canvasses to be the ideal minimum age for marriage.

Some of the major limitations of early marriages on the rights of the Nigerian child emanated from the very stiff opposition from religious groups and traditionalist. ${ }^{7}$ The main opposition came from the northern States of Nigeria where islam is the predominant religion. The proponents of the islamic religion contended that some provisions of the proposed law, that is Child Rights Act was inconsistent and largely incompatible with islamic beliefs, values and injunctions. Girl child marriage is prevalent and widely practiced in the northern States of Nigeria and the practice is not inconsistent with islamic values and traditions. This stiff opposition led to the setting up of a special committee with a view to harmonizing the provisions of the Child Rights Bill with religious and customary beliefs. ${ }^{8}$ The reason adduced for child marriage is "to prevent 'indecency' associated with premarital sex or for other cultural and religious reasons."As to be expected, the main opposition was targeted at a provision in the proposed law, setting 18 years as the minimum age for marriage. Again, the Moslems were opposed to any attempt to outlaw female genital multilation (FGM) which is culturally and traditionally justified. Indeed, FGM is

\footnotetext{
${ }^{1}$ See Article 16(1)(a) of the CEDAW.

${ }^{2}$ Peters loc. cit.

${ }^{3}$ Ibid.

${ }^{4}$ These include Lagos, Ogun, Oyo, Ondo, Ekiti, Osun, Edo and Delta States of Nigeria.

${ }^{5}$ Ibid.

${ }^{6}$ This can be contrasted with the requirement under the Marriage Act which provides for "twenty-one years".

${ }^{7}$ United States Department 2007 Country Reports on Human Rights Practices" in Nigeria, 11 ${ }^{\text {th }}$, March, 2008

${ }^{8}$ The National Assembly did not give any official reason for its action.
} 
still practiced in the country. ${ }^{1}$ Approximately, 19 percent of the female population had been victims of FGM, although the practice had declined steadily in recent years.

In view of the opposition to the Child Rights Bill, the National Assembly threw out the Bill in October 2002. Though, the Child Rights Act was eventually enacted and passed into law, ostensibly, due to public outcry and criticisms against the action of the National Assembly by international bodies and civil society organizations.

Finally, the act of respecting and upholding the tenets of tradition and religion over and above legislative provisions leaves much to be desired in our struggle against early marriage.

\section{The Need for Socio-Legal Interventions in Curbing Child Marriage}

Weak laws and inadequate implementation of the laws result in early marriages being conducted with impunity. In fact, advocates ${ }^{2}$ against child marriage argue that the conviction rate in breach of the prohibitions against child marriage in most countries is nil. Child marriage exists in the context of other gender-based unequal laws and practices. Enforcement of laws on discrimination and violence against women must exist side by side with the implementation of laws against child marriage. It is clear that international human rights conventions concerning child marriage remain at best rhetoric, or general declarations of principles, without effective national policies and mechanisms for their implementation and enforcement. There is now a pressing need to to do things differently, if the international agreement by governments within the last decade, particularly the The International Conference on Population and Development (ICPD), the Fourth World Women's Conference and more recently the millenium Development Goals are set to become a reality. Child marriage remains a widely ignored violation of the girls and young women's health and development rights.

Government are often either unable to enforce existing laws or disagree with national marriageable age laws and customary and religious laws. This is due to the "official tolerance of cultural, societal and customary norms that shape and govern marriage and family life ${ }^{3}$. In general, when it comes to violation of the girls ' right, there is rarely political will to act. Child marriage is culturally packaged as a social necessity, but this in many cases amounts to "a child's socially licensed sexual abuse and exploitation. ${ }^{4}$.It is one of the most enduring forms of girls and young women being sanctioned for sexual abuse. The social acceptance of the arrangement does not diminish the reality of a girl being deliberately exposed to sexual abuse and exploitation, usually by her parents and family. ${ }^{5}$

The current global waves in gender equality and the quest for liberation of women from socio-cultural shackles have brought early marriage into global limelight. Sociologists, Counselors, Anthropologists, Health Experts, Public Affairs Analysts as well as Scholars in religious studies have made intellectual strides in this direction to address the bane of child marriage; and the urgent need for socio-legal interventions in curbing the bane of child marriage. It is a huge responsibility for a young girl to become a wife and mother and because such girls are not adequately prepared for these roles, this heavy burden has a serious impact on their life. Women who marry early are more likely to suffer abuse and violence, with both psychological and physical consequences inevitable. Violent behaviour can take the form of physical harm, psychological attacks, threatening behaviour and forceful sexual acts including rape. Abuse is sometimes perpetrated by the family of the husband, as well as by the husband himself, and girls who enter families like a bride often become domestic slaves to their in-laws. There is urgent need for socio-legal interventions in curbing the menace of child marriage. Such intervention to address child marriage in communities includes:

1. Bringing men and traditional rulers on board: Religious leaders and traditional rulers have played a key role in speaking out against child marriage and changing community attitudes.

2. Educating and Empowering Girls: Education is one of the most powerful tools to delay the age at which girls marry as school attendance helps shift norms around child marriage. Improving girls access to quality schooling will increase a girl's chances of gaining a secondary education and helps to delay marriage. When a girl in the developing world receives seven or more years of education, she marries on average four years later. Empowering girls by offering them opportunities to gain skills and education, providing support networks and creating safe spaces where girls can gather and meet outside the home can help girls to assert their right to choose when to marry.

3. Mobilizing and Educating Communities: Laws alone won't end child marriage. In many instance legislation is not implemented, since many local authorities are unwilling to see themselves as intervening in the family's private relations. Many are simply unaware of the scale of child marriage and the harmful impact it can have.

\footnotetext{
${ }^{1}$ Female Genital Mutilation, World Health Organization <http://www.who.int/mediacentreffactsheats/fs241/en> accessed 3 April 2020. ${ }^{2}$ Supporters of Child Rights Act, Convention of the Rights of a Child et al.

${ }^{3}$ Centre for Reproductive Rights Reproductive Rights: 2000 Moving Forward, (New York: Centre for Reproductive Rights, 2000) 52 .

${ }^{4}$ Forum on Marriage and the Rights of Women and Girls, Early Marriage: Sexual Exploitation and that of Human Rights of Girls, (London: International planned parenthood Federation (IPPF), 2001 at 6.

${ }^{5}$ Ibid
} 


\section{Conclusion}

One of the specific objectives of this paper was to appraise early marriage as it pertains to marriageable age. The paper highlighted the fact that child marriage is still very prevalent in Nigeria, especially in the northern part of the country. It further expressed the view that despite the explicit criminalization of early marriages in Nigeria, incidences of early marriage have continued unabated. Early marriage constitutes a serious breach on the fundamental rights of the Nigerian child. A multifaceted approach through mass enlightenment and grass root door-to-door campaign is necessary to tackle the menace of child marriage. Importantly, marriageable age of 18 and above for the girl child should be made a fundamental right under chapter iv of the Constitution of the Federal Republic of Nigeria 1999 as amended.

\section{REFERENCES}

Adegbite K (2017) What The Law Says About Marriage And Divorce: Answer to All Your Questions Global Image Books \& Publishers at 145.

African Charter on the Rights and Welfare of a Child (1990) (ACRWC) Convention on the Rights of the Child (1990).

Ashiru, M.O.A (2007) Gender Discrimination in the Division of Property on Divorce in Nigeria Journal of African Law vol 51. No. 2316 at 325-326.

Bayisenge J, Early Marriage as a Barrier to Girl's Education: A Developmental Challenge in Africa available at: $<$ www.ifuw.org/fuwa/docs/Earlymarriage.pdf\&ved=0CA8QFjAA\&usg=

AFQjCNHoNVrxGRe3LvOSL3cvnvq17Vxw> accessed 27 May 2020.

Broomley, P.M Family Law (1981) London: $6^{\text {th }}$ ed., Butterworths at $16-18$.

Centre for Reproductive Rights Reproductive Rights: 2000 Moving Forward, (New York: Centre for Reproductive Rights, 2000) 52.

Child Rights Act, (2003). Cap C50 Laws of the Federation of Nigeria (LFN) 2004.

Ciniblak, K.L. Partner Choice, Arranged and Forced in the Dutch Multicultural Society $<$ www.movies.ni/huweliksdang $>$ accessed on 24 May 2020.

Constitution of the Federal Republic of Nigeria, 1999 as amended.

Cretney, S.M. and Masson, J.M., (1990) Principles of Family Law London: 5th ed. Sweet \& Maxwell at 34.

Elizabeth W (2004) Behind the Wedding Veil; Child Marriage as a Form of Trafficking in Girls, vol. 12 No. 2, American University Journal of Gender Social Policy and the Law at 247.

Fayokun, K.O., (2015) Legality of Child Marriage in Nigeria and Inhibitions against Realisation of Education Rights US-China Education Review B, Vol. 5 No. 7460 at 461.

Female Genital Mutilation, World Health Organization <http://www.who.int/mediacentreffactsheats/fs241/en> accessed 3 April 2020.

Forum on Marriage and the Rights of Women and Girls, Early Marriage: Sexual Exploitation and that of Human Rights of Girls, (London: International planned parenthood Federation (IPPF), 2001 at 6.

Gbadamosi, O. (2007) Reproductive Health and Rights (African Perspectives and Legal Issues in Nigeria) BeninCity: Ethiope Publishing Corporation at $290-291$.

Matrimonial Causes Act (MCA), 1970 cap M7 LFN 2004.

Megan Arthur et al. (2014) Legal Protections against Child Marriage around the World. World Policy Analysis Center, MACHEquity at 3.

Muftau, R., (2016) An Appraisal of the Legal Rights of Women in Nigeria Journal of Law, Policy and Globalization, vol. 52,69 at 69 .

Nnadi I (2014) Early Marriage: A Gender Based Violence and a Violation of Women's Human Rights in Nigeria", Journal of Politics and Law Vol. 7, No. 3 at 35.

Nwogugu, E.I (2011)Family Law in Nigeria (Revised Edition) Ibadan: HEBN. Publishers Plc at 24

Onokah M.C (2003) Family Law Ibadan : Spectrum Books Limited at 124.

Onuora O and Olayinka A., (2015) Sexual Abuse and Child Marriage: Promise and Pathos of International Human Rights Treaties in Safeguarding the Rights of the Girl Child in Nigeria Child Abuse Research: A South African Journal Vol 16(2), 78 at 80.

Peters D., (2000) The Domestication of International Human Rights Instrument, and Constitutional Litigation in Nigeria Netherlands Quarterly of Human Rights, vol. 18(3), 357 T373.

Rangita de Silva-de-Alwis (2008) Child Marriage and the Law: Legislative Reform Initiative Paper Series, (New York: UNICEF Division of Policy and Planning at $1-76$.

Sagay IE (1999) Nigeria Family Law; Principles, Cases, Statutes and Commentaries, Lagos: Malthouse Press Limited at 52

The Age of Marriage Law Cap 6 Laws of Eastern Nigeria, 1963.

The Convention on Consent to Marriage Age for Marriage and Registration of Marriage 1964. 
The Convention on Consent to Marriage, Minimum Age for Marriage and Registration of Marriages 1962.

The Convention of the Elimination of all Forms of Discrimination Against Women (CEDAW) 1981

The Convention on the Rights of the Child 1989.

The Inter-African Committee (IAC) on Traditional Practices Affecting the Health of Women and Children (1993) newsletter, December 2003 at 1.

The Marriage, Divorce and Custody of Children Adoptive Bye-Laws Order, 1958 of the Western States, Western Region L.N 456 of 1958.

The Matrimonial Causes Act 1970 cap. M7 Laws of the Federation of Nigeria 2004.

The Native Authority (Declaration of Biu Native Marriage Law and Custom) Order 1964.

The Native Authority (Declaration of Idoma Native Marriage Law and Custom) Order 1956

The Native Authority (Declaration of Tiv Native Marriage Law and Custom) Order 1955

The Native Authority (Declaration of Borgu Native Marriage Law and Custom) Order 1961.

Tonwe, S.O and Edu O.K, (2007) Customary Law in Nigeria Renaissance Law Publishers Limited at 151-161.

United States Department 2007 Country Reports on Human Rights Practices" in Nigeria, 11 ${ }^{\text {th }}$, March, 2008. 